Original article

\title{
Cooperation of social workers of non-state non-profit organisations with the Integrated Rescue System staff during critical incident situations
}

\author{
Veronika Mia Zegzulková *, Marie Špiláčková \\ University of Ostrava, Faculty of Social Studies, Department of Social Work, Ostrava, Czech Republic
}

\begin{abstract}
The topic of cooperation during critical situations is highly topical both on the Czech and international levels. Professional discourse on climate change as a precursor of major floods and devastating earthquakes, or growing fears of terrorist attacks is becoming more common. As the frequency of these situations grows, there is also a growing need for their comprehensive and effective management. The submitted paper aims to map the area of cooperation of social workers working for non-governmental non-profit organisations with the Integrated Rescue System staff in critical incident situations. The goal was achieved through qualitative research using structured interviews with open questions. The main output is the finding that there is a lack of adequate legislation defining cooperation between the concerned entities. Thus, cooperation is only dealt with on the basis of mutual contracts, agreements, and standards. The research findings also point to the shortcomings that occur in the context of mutual cooperation. By overcoming defined barriers of cooperation, the system of cooperation of social workers employed by non-governmental non-profit organisations and the Integrated Rescue System workers in critical situations can be made more effective.
\end{abstract}

Keywords: Cooperation; Critical incident; Integrated Rescue System; Non-state non-profit organisation; Social work

\section{Introduction}

Ensuring effective cooperation is crucial for the high-quality and efficient rescue and disposal works during critical incidents (CI). For example, Choi (2010) and Benson et al. (2016), to name a few foreign authors, note this issue. Štětina et al. (2014) define CI as " $a$ state in which there is an accumulation, loss, or release of certain substances, energy, or forces that have a harmful effect on the population, environment, economy, material and cultural values". In other words, CI is the harmful impact of forces and phenomena triggered either by human activities (e.g. terrorism, major traffic accidents, increased migration, fires, etc.) or by natural influences (e.g. earthquakes, tsunamis, floods, epidemics, etc.), or even by accidents. Although the coordination of this cooperation between the entities providing assistance to the victims of $\mathrm{CI}$ is only in its infancy, the Czech Republic encourages and emphasises this cooperation on its territory. This is due to the relatively high occurrence of CI throughout the Czech Republic, as evidenced by the data provided by the General Directorate of the Czech Fire Rescue Service, based on which a map was created in the geoinformation system (CArcČR (Fig. 1).
In the case of $\mathrm{CI}$, the intervention chief commander through the operational and information centre of the regional Fire Rescue Service (hereinafter referred to as "FRS") may request additional forces and means to solve CI. These are usually non-governmental non-profit organisations (hereinafter referred to as NGOs), with which they may cooperate to combat CI and provide specific activities (e.g. psychological and social care for the affected population). According to Matoušek et al. (2013), NGOs are organisations set up by an entity other than the state. Such organisations are usually set up to provide social services, and are not intended to produce profit. In the Czech Republic, NGOs providing humanitarian aid (for the purposes of research the following organisations were selected: ADRA, charitable trust, Člověk v tísni [People in Need], charitable trust, Caritas ČR) mainly deal with CI. In the case of environmental or industrial accidents, crashes, natural disasters or other threats accompanied by threats to life, health, property, and the environment, with no chance of averting threats by ordinary activities of the administrative authorities and the sections of the Integrated Rescue System (hereinafter referred to as IRS) Act No. 240/2000 Coll., a state of emergency is immediately announced.

\footnotetext{
* Author for correspondence: Veronika Mia Zegzulková, University of Ostrava, Faculty of Social Studies, Department of Social Work, Českobratrská 16, 70200 Ostrava, Czech Republic; e-mail: veronika.zegzulkova@osu.cz http://doi.org/10.32725/kont.2018.009 


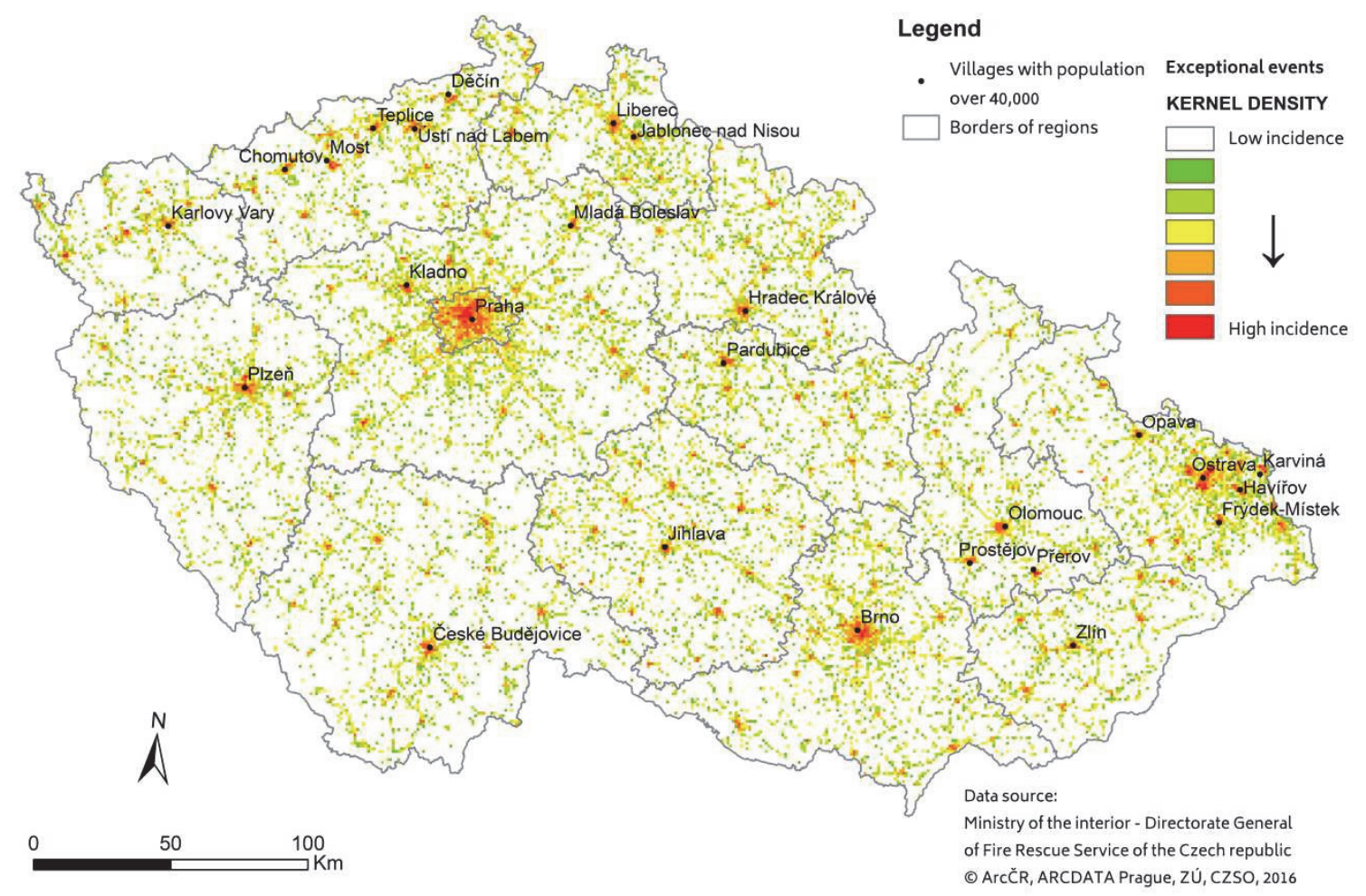

Fig. 1. Geoinformation map of the critical incident occurrence in the Czech Republic between 2015-2017

The tasks and activities of NGOs are listed in a catalogue entitled: Typified Activities of the IRS Sections (2012, p. 26), compiled by the Ministry of the Interior and the Directorate General of the Czech Fire Recue Service: "Psychosocial and humanitarian aid provided by NGOs is organised and performed taking into account the needs, manifestations, and values of the affected persons. The relationship of NGO staff to those affected is based on respect, partnership, and cooperation." However, it should be mentioned that the typified activities issued by the Directorate General of the Czech Fire Recue Service are not a dogma and it is always up to an intervention chief commander how NGOs are used.

Each NGO approaches a CI solution in its own way, which can vary. This is mainly due to the professional focus of its main activities, internal structure, staffing, and financial possibilities. The key activity is the coordination of all NGO activities and the willingness to act in a united way towards local government and the IRS in the provision of aid; which can be achieved by the creation of a single communication platform to coordinate activities and exchange information. The Ministry of the Interior, in cooperation with the Fire Rescue Service in their Catalogue of Typified Activities, presents the basic offer of activities that NGOs are able to provide in critical situations (Typified Activities of the IRS..., 2012):

- Monitoring the extent of damage and social needs.

- Material aid, equipment lending (dehumidifiers, small appliances).

- First aid, volunteer aid (in case of removing the consequences of CI).

- Psychosocial assistance (short-term and long-term interventions in cooperation with FRS psychologists, representatives of other NGOs and clergy).
- Evacuation centres - their establishment and ensuring of their operation in cooperation with the local government and the IRS.

- Financial assistance - only in the case of the acquisition of financial resources or of a public collection announcement and on the basis of a field survey.

\section{Types of assistance during the critical incident}

The first psychological assistance is provided for two groups. The first group involves direct victims (persons with non-physical injuries and light physical injuries, or dying persons) with the second group consisting of their family members. It is an immediate response to the basic psychosocial needs of $C I$ victims. Psychological assistance serves to treat basic survival needs, information and contact with families (Baštecká et al., 2005). In relation to this, Dewolfe (2014) discusses the tasks and goals of social workers during CI: ensuring protection against further damage and accompaniment to a safe place, taking care of the basic needs of survivors, providing people with a sense of security, helping with orientation and reassurance, helping survivors to contact families, etc. The greatest risk in the area of the psychological consequences of critical incident victims is post-traumatic stress disorder, suffered by millions of people around the world as a result of exposure to a catastrophic event. Tress et al. (2008) report the following symptoms of post-traumatic stress events: repeated trauma (compulsive memories, nightmares), a persistent feeling of being stunned and emotional apathy (indifference, absence), and vegetative irritability (easily frightened, insomnia).

Rescue and disposal works are directly stipulated in the Act No. 239/2000 Coll. For the purposes of this Act, the rescue works are a set of activities that lead to the elimination of the immediate impact of risks to life, health, property, and envi- 
ronment. The disposal works are created to eliminate the consequences of a critical incident.

The key objective of crisis intervention during CIs is the prevention of post-traumatic stress disorder, described above. If the disorder progresses into an advanced stage, an intervening professional is assigned to restore the client's mental powers and to overcome the traumatic experience (this is an individual method of crisis intervention). One of the methods used to cope with a traumatic event is the so-called Critical Incident Stress Management (hereinafter referred to as "CISM"), created by Müller-Leonhardt et al. (2014). The method is focused on problem identification and immediate help, using discussion, support, and awareness of the meaning of stress, post-traumatic disorder, etc. It is used both at the site of intervention and during other sessions (Vodáčková et al., 2012). Post-traumatic stress disorder provoked by natural disasters is also discussed by Bromet et al. (2017) and Sakuma et al. (2015).

According to Baštecká et al. (2005, p. 178), early intervention or debriefing means "short-term psychosocial help provided after traumatic events". Early intervention describes crisis intervention techniques used in handling the burden arising from CI. This technique can be used both individually and in a group, and is a combination of discussion and education. Benson et al. (2016) discuss early or also primary intervention in terms of proposing and implementing appropriate strategies to help victims of disasters and terrorism in the context of a spiritually sensitive helpful relationship.

Humanitarian aid most often provided in the aftermath of humanitarian crises (often following natural disasters) responds to a current lack of balance in the area of basic living needs, the occurrence of poverty, or long-term poor social conditions. Typical humanitarian aid activities include the provision of shelter (temporary shelters, distribution of tents), food distribution, medical treatment, refugee camps, and many others (Raskovic and Mrdja, 2013). Other authors such as Noble et al. (2014) define the consequences of disasters as an event that seriously disrupts the normal functioning of the victim.
The psychosocial help to victims of disasters according to Jong and Kleber (2003, p. 202) "is what the organisation does in relation to problems and needs that are of a psychological (affecting feelings, behaviour, thinking) and/or a social nature (affecting mostly the necessary support for the municipality to cope with the resulting burden)".

The follow-up professional help acquires its form based on the needs that vary after each critical incident. According to Helus (2011), the victim's/client's environment, the social group of which he/she is a member, plays a very important role during the follow-up professional help.

\section{Research focus}

Cooperation between NGOs and IRS during critical situations is only in its infancy in the Czech Republic. Due to the lack of adequate legislation, cooperation is solved only on the basis of mutual agreements and standards. The aim of the research is to map out the area of cooperation of social workers working for non-governmental non-profit organisations and integrated rescue system workers in emergency situations, to define the barriers between the concerned entities and to describe specific activities that social workers may encounter in cooperation with IRS staff during CIs.

\section{Materials and methods}

For the purpose of the survey, the deliberate (purposive) sampling technique and the "snowball" method were used. The interviews were conducted with 7 respondents. This number of respondents provided sufficient information to achieve theoretical saturation. Respondents can be divided into two groups: social workers employed in an NGO (because of the unavailability and unwillingness of other selected workers in the other units to participate in the interview, despite that they were contacted, the only respondents representing IRS were firefighters, yet we still consider the Fire Rescue Service unit staff responses to be sufficient for all IRS forces) and the IRS workers (Table 1).

Table 1. Socio-demographic characteristics of respondents

\begin{tabular}{lcccccc} 
& Interview date & Gender & Age & Profession & No. of interventions during CI & Local area (Region) \\
\hline R1 & 19.12 .2016 & F & 30 & social worker & 2 & Moravian-Silesian \\
R2 & 29.12 .2016 & M & 38 & chief commander of FRS unit & 5 & Moravian-Silesian \\
R3 & 29.12 .2016 & M & 24 & Fire fighter & 1 & Moravian-Silesian \\
R4 & 10.01 .2017 & M & 29 & social worker & 2 & Olomouc \\
R5 & 10.01 .2017 & F & 27 & social worker & Olomouc \\
R6 & 15.01 .2017 & M & 36 & social worker & 2 & Moravian-Silesian \\
R7 & 16.01 .2017 & M & 42 & chief commander of FRS unit & 4 & Liberec \\
\hline
\end{tabular}

The monographic (causal) method, a case study in synergy with the use of qualitative questioning, was selected for the fundamental research method. The main research technique was a structured interview with open questions, methodologically based on the theory of qualitative research defined by Hendl (2008).

The main aim of this research is to find examples of good and bad practice of social workers and IRS staff in the context of their mutual cooperation during critical situations. Given the generality of the main goal, this goal was divided into several sub-goals. The sub-goals of the research include:
- Sub-goal 1: To map and describe specific experiences and situations encountered by a social worker and/or an IRS worker, while providing help in CI within the framework of mutual cooperation.

- Sub-goal 2: To map examples of good and bad practice in cooperation between NGO staff and IRS workers in CI situations.

- Sub-goal 3: To map and describe the key elements in the preparation of a social worker or an IRS worker in terms of their mutual cooperation in CI situations. 
The interview questions reflect the goals set and the problem to be addressed, and are therefore intended to specify the researched phenomenon.

Sub-goal 1

1. Where is the main focus of cooperation between social workers and the staff of the Integrated Rescue System in critical situations?

2. What are the means for appropriate cooperation between social workers and the IRS staff in critical situations?

Sub-goal 2

1. What are the examples of good and bad practice in terms of cooperation between social workers and IRS staff in providing assistance to the victims of $\mathrm{CI}$ ?

2. To what extent are the provided materials of the cooperation standards of non-governmental non-profit organisations with the Integrated Rescue System during CI sufficient?

3. What do these standards lack?

4. Are there any coordination meetings for social workers and the Integrated Rescue System staff in place, the purpose of which is mutual exchange of experiences, evaluation of procedures, consultations on common procedures, etc.? What are the benefits of such meetings?

Sub-goal 3

1. What should be included in the compulsory training of social workers and the personnel of the Integrated Rescue System in the framework of joint trainings such as joint co-ordination trainings, etc. in critical incident situations?

2. What lessons can be learned about the possibilities of mutual cooperation in dealing with a critical incident for the educational preparation of social workers and staff of the Integrated Rescue system?
3. What is it that is usually neglected in the preparation of social workers and the Integrated Rescue System workers in the framework of their mutual cooperation in critical incident situations, even though it can play a key role in practice?

All questions were verbally verified during the interviews to ensure the highest possible quality of the research. Furthermore, an open encoding technique according to Švaříček et al. (2007) was used to analyse the data obtained from the interviews.

As a result of the open encoding, some recurring phenomena were identified. The groups of concepts that show a certain relationship to the given phenomenon were created - they are linked together thus enabling the formation of categories. The categories were organised into a particular storyline, based on which the text was compiled so that the content of individual categories could be retold (Strauss and Corbin, 1999). The resulting categories are listed in Table 2 . Due to the limited extent, only the selected categories will be interpreted.

\section{Analysis and interpretation of sub-categories Preparation}

The key elements of effective joint coordination preparation include, in particular, staff training. Weaknesses are seen by NGO respondents at a low level of training, lack of practical training or the fact that these trainings are in most cases only implemented within specific NGOs. "So, I'm taking the critical incident trainings or the first psychological assistance trainings in our organisation, where my more experienced colleague tells us about what it's like during the intervention, but firstly, the training's not mandatory, and secondly, it's just NGO-only events" (R4).

In terms of joint coordination training, three interviewed IRS workers see a key role, specifically in mutual awareness.

Table 2. Grouping of codes into categories

\begin{tabular}{|c|c|c|}
\hline Categories & Codes & Comment (exact citation) \\
\hline \multirow{4}{*}{ Preparation } & Training course & We're preparing for the future; preventive preparation method \\
\hline & Mutual awareness & $\begin{array}{l}\text { Who we can contact there; } \\
\text { to define what is before and follows after the incident }\end{array}$ \\
\hline & Trainings & Clarifying of individual activities; training of joint coordination \\
\hline & Meetings & Panel meetings; the crisis team meets $1 \times$ every 2 months \\
\hline \multirow{4}{*}{ Cooperation } & $\begin{array}{l}\text { Means (personal relations, material } \\
\text { and non-material means) }\end{array}$ & $\begin{array}{l}\text { We are on call; } \\
\text { Good awareness of the situation, people, and field; } \\
\text { We have established personal relationships }\end{array}$ \\
\hline & Examples of good and bad practice & Making contact; Clearly defined tasks; I don't have so much experience from practice \\
\hline & Chaos at the $\mathrm{CI}$ site & The lack of control; I then lose track and I don't know who I have on site \\
\hline & Reporting to a chief commander & I then lose track; Firefighters require information \\
\hline \multirow{5}{*}{ Background } & Systemisation & $\begin{array}{l}\text { As if no one ever tried to solve it; } \\
\text { These two sectors are completely missing each other }\end{array}$ \\
\hline & $\begin{array}{l}\text { Local and temporal extent of } \\
\text { functions }\end{array}$ & $\begin{array}{l}\text { It differs by region; } \\
\text { It happens once every five years; Everywhere it's different }\end{array}$ \\
\hline & Efforts to approach the cooperation & No formal means exist; I see the panels as an effort to start cooperation \\
\hline & Legislative framework & $\begin{array}{l}\text { It's "punk"; } \\
\text { Nothing is legally stipulated }\end{array}$ \\
\hline & Standards & $\begin{array}{l}\text { We have nothing written; } \\
\text { Elaborated methodology sheets }\end{array}$ \\
\hline
\end{tabular}


Social workers arriving at the incident site must be made familiar with the system of coordination that has been set up on site. According to firefighters, it is necessary for NGO staff to immediately report to the appointed chief commander upon their arrival at the site, primarily to maintain effective coordination when removing CI aftermath. The IRS staff have this cooperation in their job description, for which methodology sheets have also been developed. "Each IRS worker has the cooperation with others and there are methodological sheets developed to meet this goal" (R7).

Another important part noted by the respondents was the training of common procedures in the context of joint trainings. The respondents agreed on certain informality and irregularity in the organising of such joint trainings. Three respondents mentioned very rare cases when they were or could be part of a coordinated seminar, in most cases such seminars were organised by IRS forces and only invited social workers to be part of them in exceptional cases. "No, no such offer has reached us...we just don't know about it. The maximum is the first aid training, where we receive a very good-quality training, but it's the initiative of our management" (R5). Research has shown that both social workers and IRS staff are interested in being part of these practical seminars. The firefighters' interest is primarily connected to implementing a measure that is to prevent the occurrence of chaos directly at the CI site. "... it would definitely be good...we sometimes are in each other's way at the site...I mean not us, but those people from non-profit organisations [laughs]. So, it might help to specify who, what, where, and how we do it in a hurry" (R3).

The last important part of the training is, according to the respondents, a certain type of meeting, most often in the form of panel meetings. It is at these meetings that social workers of NGOs meet the IRS staff, apart from their joint action in CI situations, and where they discuss the possibilities of mutual cooperation within the panel meetings. The respondents understand the purpose of panel meetings as a preventive method to address the consequences of $\mathrm{CI}$ in terms of functioning and the most effective follow-up cooperation. "There is a crisis team meeting once every two months and it's a meeting of social workers and IRS staff. If these meetings are beneficial, I can't say, because I don't participate" (R7).

\section{Cooperation}

According to the respondents, an essential part of effective cooperation is the means functioning as certain tools. The means can be divided into material and non-material resources based on individual interviews. The perception of resources is very subjective, not only in terms of individual professions (a social worker/an IRS worker), but also from the point of view of individual respondents. The IRS staff have talked about the means in terms of interconnection of all entities and the follow-up easy ensuring of cooperation. "One could find the contacts for all non-profit organisations in the Operations Centre, and so then they call directly from the headquarters to the Integrated Security Centre" (R12). A key role (both in the form of the means for good cooperation and coordination) generally belongs to personal ties. Well-functioning ties and a mutual respect can ensure effective cooperation. "In my opinion, although it's not probably a means but a respect for both of the unit... because what I see as the most problematic is that it hasn't been respected... So, the relationship is not very close and then it doesn't work" (R4).

The interview also included examples of good and bad practice. Social worker respondents mostly consider good practice the situations when they are called to a critical incident site and are provided with basic information, such as how they can help, information about pre-selected victims/localities. A key element is also the speed of information exchange or the speed of "contact" of social workers by firefighters. The situation also varies according to the type of CI, where it is clear from interviews that firefighters sometimes ask for help from NGOs during the outbreak of $\mathrm{CI}$, on other occasions the IRS units pass the work to social workers only after the completion of their duties. "... We're the ones who work only after the CI is ove... after IRS forces leave the area. When they are finished with their activities, they assign it to us and we continue to look after the victims for several months (...) we need to wait for activation... that's what I've agreed with IRS what they need from us" (R6). Despite the examples of a functional system, respondents' statements also show the examples of "bad practice" in terms of lack of respect, inefficient coordination and poor cooperation. "... What I perceive as the most problematic is that there is no respect... the fact is that the NGOs think they (the IRS) are perfect... that they will do it all, and then the firefighters are not bothered while the cops think they are masters, so why would they be wasting their time with some social workers? So, the relationship is not very good and then it doesn't work" (R4).

Due to poor cooperation, there is often chaos at the CI site. These chaotic situations, when the chief commander of the intervention usually fails to register all the participants providing assistance at the scene of the incident, are preceded by the lack of organisation on the part of social workers from NGOs. The situation at the CI site is very confusing. Preventing this unnecessary chaos, according to the IRS respondents, can be very easily done by immediately reporting to a chief commander of the intervention after arrival at the CI site, (which, as the research shows, is most often the commander of the Fire Rescue Service unit), and then waiting for the handing over of individual assignments. According to the social worker respondent, it is also possible that chaos arises because of too many participating NGOs that have not sufficiently clarified their area of assistance. One respondent also adds that in order to prevent this situation, a meeting in which the NGOs involved will agree on the extent of their responsibilities is required. At the same time, the respondent suggests two possible solutions, namely the determination of responsibilities according to the site of occurrence of the victims or the length of the assistance provided to the victims of CI.

\section{Background}

It is clear from the definitions and analyses of the previous two categories that, in general, something that is significantly lacking in mutual cooperation during CI is diversity of the trainings and procedures of the incident participants. Most of the respondents clearly agree on the need for greater systematisation of cooperation at a CI site. The respondent from the IRS section talks about the unanchored needs of NGO social workers. The IRS system has clear competencies and procedures and finds no deficiencies in the system. At the same time, one respondent proposes a variant in terms of adapting to NGO requirements in order to work more efficiently together. "Well, that's exactly what NGOs need to say, what else they want, what they need, and what should improve. I don't know whether it should be, for example, better time availability" (R2). "Our coordination is going well, I think it works" (R1).

An important role in both the preparation and the cooperation of the staff is played by the local and temporal extent of their functions. From the interviews it can be concluded that where there is a higher and more frequent occurrence of $\mathrm{CI}$ (especially of a natural disaster type CI), there is also better training for this incident, and the follow-up staff's coopera- 
tion is more effective. In all the interviews, I encountered a situation where, after a certain statement on how the system works in a respondent's local area, the respondent added that in each region "it" works differently. The different occurrence of CIs also results in the low experience of social workers and IRS staff with possible cooperation. As reported by the female respondent no. 1 , who had provided assistance in two incidents in about ten years of her experience. "Yeah, I was in two incidents in all that time" (R1).

The effort to approach the issue - especially on the social workers' part - can be based on their statements that the situation in the context of the anchoring of workers' cooperation is still being addressed, is constantly improving and developing. It talks about the need for better organisation of preparations for the provision of assistance as well as procedures for cooperation with IRS staff. "In my opinion, it should be certainly approached systemically. But those efforts probably exist, but I don't know how realistic it is" (R1). In contrast, the IRS staff were sceptical in this respect. They noticed initial efforts that have not been brought into a continuing reality. They illustrate the situation by the example of joint meetings where there are always some non-functioning elements (whether in communication or in the overall organisation of assistance). These will be compiled and evaluated, but nothing will change in practice - even though the resolving and correcting of these drawbacks would mean preventing the "bad practice" and would in many ways make it easier for all entities providing assistance at the CI site.

One of the respondents talked about the legislative framework as a possibility of a nationwide anchoring of the cooperation between the staff involved in CIs. The above proposal is, in my opinion, very important for this research, because the theoretical part of the paper has shown and again reminded us that the cooperation of social workers of NGOs with IRS staff in CIs is not legally treated in any way, and therefore there are no specific legal measures in place. "I feel like it's all just halfbaked... that there's nothing legally stipulated or some clear legislative framework is missing... and then of course it again varies by region" (R1).

The creation of common standards is closely linked to the creation of a legislative framework. The existing standards for the CI needs were developed under the work by the IRS forces and bodies. These standards are also followed by social workers, who are involved in CIs, due to the basic definition of their activities in these standards. All social workers surveyed agreed on the fact that they have no developed standards. Some of them have never been made familiar with any standards. "The fact is that standards of social services don't include any critical incidents, and we're missing the IRS standards at the same time. It could be replaced with joint meetings and trainings" (R5).

\section{Results and discussion}

The information provided by both Czech and foreign scientific literature matches the information resulting from the research carried out, that is with the answers of the social workers and the IRS staff. According to the Decree No. 505/2006, the content of personnel standards is mainly constituted by the personnel and organisational provision of the social services and the professional development of the employees, which is ensured by the concerned organisations. The written internal organisational structure provides for authorisations and responsibilities of individual employees. Also, the internal rules for the recruitment and training of new employees and natural persons must be provided in writing and strictly followed by the social service provider. Other personnel requirements include continuous skill development, work with volunteers and trainees, and the provision of supervision.

As for the training and seminars of social workers in CIs, according to Úlehla (2005, p. 116), the search for new courses will depend on "an active interest of social workers rather than on an attractive offer from employers. However, continuous training of social workers is one of the conditions of meaningful work". This corresponds with the statements of social workers who talk about their own initiative in non-compulsory education. "Together with other non-governmental organisations, we initiated the creation of panel discussions to which NGOs are now being recruited, with the representatives of psychosocial assistance from all the units being invited there for us to be able to meet together" (R6). This issue is also partly dealt with by Cooper and Briggs (2014), who point to the fact that there is a lack of elements in professional training of social workers to prepare them for specific activities during CIs, and suggest curriculum initiatives that include not only concepts and principles of assistance in the situation of $\mathrm{CI}$, but also their simulations and practical scenarios. Also, for example, Ruth and Marshall (2017) discuss the need for professional development of social work in situations of disasters and crisis events. Glumbíková et al. (2018) state that personal reflexivity is necessary for described personal development and management of the demands of the practice of social work.

Also, the fact that IRS staff have a wider range of training and courses than NGO staff, resulting from interviews, is confirmed by Doležal and Lapka (2011) who claim that, unlike the training of the IRS staff, the training of social workers in CIs is not so developed; to illustrate this, the authors mention a professional self-defence course or an English language course directly organised for the IRS staff.

Havrdová (1999) notes the competencies of social workers in general. These competences match the respondent statements, specifically within the compulsory study, during which social workers should acquire the above-listed key competencies.

Also, the results of the second part of the research match the theoretical level statement. This is illustrated by the key elements of assistance provided by a social worker in CI situations, where according to Černá (2008), it is essential to seek out clients in their natural environment, to help in reducing security and health risks, as well as the methodical management of volunteers and subordinate staff at a CI site. These activities were also described by respondents from NGOs.

The need for mutual respect and mutual support among social workers and IRS staff is reflected both in professional publications and in the collected respondent statements. Baštecká et al. (2005) declare that the main support to the involved social worker should be a well-functioning team, followed by the development of key requirements for an effective and clearly defined organisation of an intervention - which are detailed in the theoretical part of the paper and fully correspond to the information provided by the respondents.

The tasks and activities of NGOs are listed in the Catalogue of Typified Activities (2012) prepared by the Ministry of the Interior and the General Directorate of the Czech Fire Rescue Service. The social workers have talked about these specific activities being sufficient for the performance of their work in CI situations.

The real life situations mapped by respondents' statements also made it possible to infer specific activities that social workers can encounter in CIs in cooperation with IRS staff. 
These activities include in particular:

- Provision of psychosocial support to the victims of CI.

- Provision of a sense of security to persons affected by CI.

- Monitoring of victims and subsequent provision of assistance, based on identified needs of victims of CI.

- Provision of material assistance to the victims of CI (drinking water, sanitary aids, clothing, etc.).

- Provision of advice to the victims of CI (provision/mediation of contacts, administrative tasks, etc.).

- Gathering information about the needs of the victims of CI and their subsequent transfer to specialized experts (psychiatric and rehabilitation facilities, etc.).

- Cooperation with IRS staff in searching for victims who may need help.

- Moral support ("running errands and dealing with different authorities", assistance with applying for financial benefits, etc.).

- To be constantly ready to set out and arrive at a CI site in the shortest possible time.

- To be reconciled with the possibility that victims will refuse social worker assistance.

These activities are carried out either in direct cooperation with the IRS staff or on the basis of the handing over of the initial information provided by the IRS staff at the CI site to social workers.

Based on respondent statements, the need for training of common procedures in group training was also identified as a necessary part of a good preparation for the mutual cooperation of social workers and IRS staff during CIs, with respondents agreeing on a certain informality and irregularity of joint trainings and seminars.

The research also aimed to map the examples of good and bad practice in the cooperation of NGO staff and IRS staff in CI situations. The most frequently mentioned examples of good practice have clearly become the situations described by respondents as "effective transfer of information".

The social worker respondents generally talk about good practice in cases where they are called to a CI and are provided with basic information, such as how they could help, information on pre-selected victims/locations. According to the respondents, the key activity is also the speed of information transfer or the speed of "contact mediation" to social workers by firefighters. The research shows that the specific situations differ according to the type of $\mathrm{CI}$, where the interviews have shown that sometimes firefighters ask for help from NGOs already at the beginning of $\mathrm{CI}$, and on other occasions they 'pass the work' to social workers only after the completion of their own duties.

The interviewees also identified "bad practices" or examples of situations where cooperation between social workers and IRS staff did not work very efficiently. Respondents, however, indicate that the occurrence of these negative experiences is steadily decreasing, mainly thanks to ever-improving coordination. Respondents also talked about bad practice in terms of lack of respect, inefficient coordination and poor cooperation. The views of both groups of workers match the need to understand the need for mutual respect, help, and cooperation, which is seen as a prerequisite for the rapid elimination of a CI's consequences.

The negative experience by the IRS forces is still very common according to the interviewees, but at the same time they are aware of the gradual improvement of the current situation. This improvement is attributed to more frequent joint meetings and occasional joint coordination training sessions. The greatest problem is seen in the "insubordination" of social workers, who in some cases did not report to the chief commander of the intervention, who thus could not coordinate their activities, lost track of the situation at the CI site and, as a result, there was chaos. Based on the opinion of IRS members, it is very easy to prevent this unnecessary chaos by having the social workers immediately report to the chief commander of the intervention (it is most often the Fire Rescue Service commander as shown by the research) after arriving at the CI site while waiting for the handover of the assignments. Information collected from the interviews confirmed an improving situation in this respect. Social workers respect the system of IRS forces and, upon arriving at the CI site, report to the chief commander (whom they recognize according to his/her clear indication) and follow his/her instructions. For a good understanding of the overall situation, it is essential to realise that the situation is different in different places, which is also pointed out by the respondents.

The poor practice resulting from the respondent interviews is also considered chaotic due to the large number of participating NGOs that have not sufficiently clarified their areas of assistance with one another. Respondents see the solution of the situation as a meeting where the intervening NGOs agree on their activities. At the same time, the respondents propose two possible solutions, namely the determination of the extent of their activities according to the site of occurrence of victims or the length of assistance provided to the victims of CI.

\section{Conclusions}

The aim of the submitted paper was to map the areas of cooperation of social workers of non-governmental non-profit organisations and of the personnel of the Integrated Rescue System in critical incident situations. Practical experience collected from the statements of social workers and the staff of the Integrated Rescue System has made it possible to describe deficiencies that arise in the context of mutual cooperation and that require more work. Based on this information, the theoretical framework of coordination with the practice can be reflected. According to social workers and IRS staff within the framework of cooperation, the defined barriers are mainly: non-existent legislative framework, lack of joint training and seminars, lack of respect among professions or, for example, poor organisation in the preparation of joint cooperation of social workers of non-governmental non-profit organisations and personnel of the Integrated Rescue System in critical incident situations. The paper points to a broad extent of functions in the context of critical incident cooperation, and also points out the irreplaceability of the two components of help providers. The involvement of social workers in critical incidents has great potential, and it is therefore important to further develop these efforts for effective cooperation and, above all, to professionalise them.

\section{Conflict of interests}

The manuscript is the work of our authors. It does not contain any information that is fictitious, fake, or that has been previously published. All the literature and other resources that we drew on in the work are properly cited and are listed in the references. 


\section{Kooperace sociálních pracovníků nestátních neziskových organizací s pracovníky integrovaného záchranného systému v situacích mimořádné události}

\section{Souhrn}

Téma spolupráce při mimořádných událostech je v českém i mezinárodním měřítku vysoce aktuální. Odborný diskurz na téma klimatických změn jako předchůdců rozsáhlých povodní a ničivých zemětřesení nebo narůstající strach z teroristických útoků je stále častější. Stejně jako roste četnost výskytů těchto mimořádných událostí, roste potřeba jejich komplexního a efektivního zvládání. Cílem předkládaného příspěvku je zmapování oblasti kooperace sociálních pracovníků nestátních neziskových organizací a pracovníků integrovaného záchranného systému v situacích mimořádné události. Cíl se podařilo naplnit prostřednictvím kvalitativního výzkumu s využitím strukturovaných rozhovorů s otevřenými otázkami. Hlavním výstupem je zjištění, že chybí adekvátní legislativa vymezující spolupráci mezi danými subjekty. Kooperace je tak řešena pouze na základě vzájemných smluv, dohod a standardů. Výsledky výzkumu také poukazují na nedostatky, které se v rámci vzájemné spolupráce vyskytují. Překonáním definovaných bariér spolupráce může dojít ke zefektivnění systému kooperace sociálních pracovníků nestátních neziskových organizací a pracovníků integrovaného záchranného systému v situacích mimořádné události.

Klíčová slova: Integrovaný záchranný systém; Kooperace; Mimořádná událost; Nestátní nezisková organizace; Sociální práce

\section{References}

1. Act No. 239/2000 Coll [Zákon č. 239/2000 Sb., o integrovaném záchranném systému a o změně některých zákonů]. In: Sbírka zákonů České republiky, částka 73/2000.

2. Act No. 240/2000 Coll. [Zákon č. 240/2000 Sb., o krizovém řízení a o změně některých zákonů]. In: Sbírka zákonů České republiky, částka 240/2000, pp. 3475-3487.

3. Baštecká B et al. (2005). Terénní krizová práce: psychosociální intervenční týmy. Praha: Grada.

4. Benson PW, Furman LD, Canda ER, Moss B, Danbolt T (2016). Spiritually Sensitive Social Work with Victims of Natural Disasters and Terrorism. Br J Soc Work 46(5): 1372-1393. DOI: $10.1093 / \mathrm{bjsw} / \mathrm{bcv} 053$.

5. Bromet EJ, Atwoli L, Kawakami N, Navarro-Mateu F, Piotrowski P, King AJ, et al. (2017) Post-traumatic stress disorder associated with natural and human-made disasters in the World Mental Health Surveys. Psychol Med 47(2): 227-241. DOI: $10.1017 /$ S0033291716002026.

6. Choi YJ (2010). International Social Work: Professional Action in an Interdependent World. Health Soc Care Community 18(1): 108-109. DOI: 10.1111/j.1365-2524.2009.00898_3.x.

7. Černá M (2008). Česká psychopedie: speciální pedagogika osob s mentálním postižením. Praha: Karolinum.

8. Cooper L, Briggs L (2014). Do we need specific disaster management education for social work? 29(4). [online] [cit. 2018-02-10]. Available from: https://ajem.infoservices.com.au/ items/AJEM-29-04-08

9. Decree No. 505/2006 [Vyhláška č. 505/2006 Sb., kterou se provádějí některá ustanovení zákona o sociálních službách]. In: Sbírka zákonů České republiky, částka 164/2006.

10. Dewolfe DJ (2014). Psychosociální odpověd' na kolektivní násilí a terorismus: terénní průvodce. Praha: MV - generální ředitelství Hasičského záchranného sboru ČR.

11. Doležal K, Lapka T (2011). Profesní sebeobrana pro složky IZS: příručka sebeobranných zákroků s přílohou. Ostrava: Ostravská univerzita Ostrava, Lékařská fakulta.

12. Glumbíková K, Vávrová S, Gojová A (2018). The Critical Reflexivity of Field Social Workers who are Working with Families: Recommendations for the Educational Process. In: Carmo M (Ed.). Conference on Education and New Developments 2018. Education and New Developments 2018. Lisbon: inScience Press, pp. 279-283.
13. Havrdová Z (1999). Kompetence v praxi sociální práce: metodická příručka pro učitele a supervizory v sociální práci. Praha: Osmium.

14. Helus Z (2011). Úvod do psychologie: učebnice pro střední školy a bakalářská studia na VŠ. Praha: Grada.

15. Hendl J (2008). Kvalitativní výzkum: základní teorie, metody a aplikace. Praha: Portál.

16. Jong K, Kleber R (2003). Early Psychosis Interventions for War Affected Populations. Oxford: Oxford University Press.

17. Matoušek O et al. (2013). Metody a řízení sociální práce. Praha: Portál.

18. Müller-Leonhardt A, Mitchell SG, Vogt J, Schürmann T (2014). Critical Incident Stress Management (CISM) in complex systems: cultural adaptation and safety impacts in healthcare. 68: 172-180. DOI: 10.1016/j.aap.2013.12.018.

19. Noble C, Strauss H, Littlechild B (2014). Global Social Work: Crossing Borders, Blurring Boundaries Sydney: Sydney University Press.

20. Raskovic B, Mrdja S (2013). Natural disasters: prevention, risk factors, and management. New York: Nova Science Publishers.

21. Ruth BJ, Marshall JW (2017). A History of Social Work in Public Health. Am J Public Health 107(S3): S236-S242. DOI: 10.2105/ AJPH.2017.304005.

22. Sakuma A, Takahashi Y, Ueda I, Sato H, Katsura M, Abe M, et al. (2015). Post-traumatic stress disorder and depression prevalence and associated risk factors among local disaster relief and reconstruction workers fourteen months after the Great East Japan Earthquake: a cross-sectional study. BMC Psychiatry 15(1): 1-13. DOI: 10.1186/s12888-015-0440-y.

23. Strauss AL, Corbin JM (1999). Základy kvalitativního výzkumu: postupy a techniky metody zakotvené teorie. Brno: Sdružení Podané ruce.

24. Štětina J et al. (2014). Zdravotnictví a integrovaný záchranný systém při hromadných neštěstích a katastrofách. Praha: Grada.

25. Švaříček R, Šed'ová K et al. (2007). Kvalitativní výzkum v pedagogických vědách. Praha: Portál.

26. Tress W, Krusse J, Ott J (2008). Základní psychosomatická péče. Praha: Portál.

27. Typified Activities of the IRS... [Typová činnost složek IZS při poskytování psychosociální pomoci] (2012). Katalogový soubor STČ 12/IZS. Praha: MV ČR - generální ředitelství HZS ČR.

28. Úlehla I (2005). Umění pomáhat: učebnice metod sociální praxe. Praha: Sociologické nakladatelství.

29. Vodáčková D et al. (2012). Krizová Intervence. Praha: Portál. 